\title{
Self-deliberation and the Strategy of the Pseudo-dialogue
}

Received: 10/09/2019 | Reviewed: 05/11/2019 | Accepted: 10/12/2019 DOI: 10.17230/co-herencia.17.32.6

\section{Christopher W. Tindale*}

ctindale@uwindsor.ca

\begin{abstract}
The New Rhetoric identifies the self-deliberator as one of three main types of audience. But such a turn toward the self is at odds with studies of contemporary argumentation, particularly social argumentation. Argumentation takes place "out there", modifying the environments in which audiences operate. Equally interesting is the use of self-deliberation as a rhetorical strategy. Arguing with oneself, especially when that self is distanced in some way from the individual involved, employs self-deliberation beyond the ends that Perelman assigned to it. In this paper, my goal is to explore the nature of the self-deliberator as an audience and selfdeliberation as a rhetorical strategy employed in argumentation.
\end{abstract}

\section{Keywords:}

Argument schemes, Booth, Descartes, rhetorical strategy, self-deliberation.

\section{La autodeliberación y la estrategia del pseudodiálogo}

Resumen La Nueva Retórica identifica al autodeliberador como uno de los tres tipos principales de audiencia. Pero dicho giro hacia el yo no guarda concordancia con los estudios contemporáneos de la argumentación, particularmente en cuanto a lo social. La argumentación ocurre "allí afuera" y modifica los ambientes donde operan las audiencias. Resulta igualmente interesante el uso de la autodeliberación como estrategia retórica. En la argumentación con uno mismo, especialmente cuando dicho ser se encuentra de alguna manera alejado de la persona involucrada, se utiliza la autodeliberación más allá de los fines que Perelman le asignó. El objetivo del presente artículo es explorar las características del autodeliberador como audiencia y la autodeliberación como estrategia retórica empleada en la argumentación.

\section{Palabras clave:}

Esquemas de argumentación, Booth, Descartes, estrategia retórica, autodeliberación.

"Ph.D. in Philosophy from the University of Waterloo. Director, Centre for Research in Reasoning, Argumentation and Rhetoric, \& Professor, Department of Philosophy University of Windsor, Canada. ORCID: 0000-00022820-1416 


\section{Introduction: Ambrose and the Inward Turn}

Ambrose, the Bishop of Milan, presented a puzzle to those who visited him. In Book vi of the Confessions, Augustine says of Ambrose:

When he was reading, his eyes ran over the page and his heart perceived the sense, but his voice and tongue were silent. He did not restrict access to anyone coming in, nor was it customary even for a visitor to be announced. Very often when we were there, we saw him silently reading and never otherwise. After sitting a long time in silence [...] we used to go away (1991, pp. 92-93)

Thus, we are invited to picture a scene where several people are standing around watching someone else reading, and after a time, simply going away. The story is doubly strange because it describes behaviour that we would find perfectly natural (at least on the reader's part). For those witnessing it, however, this phenomenon is sufficiently unusual that it deserves to be remarked in this way. Moreover, it demands more than just a description; it must also be explained. Augustine speculates on the causes: perhaps Ambrose wants to avoid having to expound a difficult passage to interested hearers and so getting caught up in debate, thereby giving him the time to get through more books; or perhaps he wants to preserve his voice. Whatever the explanation, Augustine assures us (and himself) that "this man had a good reason for what he did" (1991, p. 93). The Pusey translation makes clearer the ethotic appeal here: whatever the intent "certainly in such a man it was good" (Augustine, 1961, p. 82).

This restoration of Ambrose's mind by reading (Augustine, 1991, p. 92) evokes a now-lost sense of recreation. Canadian author Robertson Davies in his diaries refers to a time during the construction of Massey College in Toronto when he returned home too tired to "recreate himself" (2015). This conveys the sense of the self having been dispersed over the course of the day, and requiring an activity in which that self is collected and rebalanced, or recreated.

Two things emerge from these anecdotes: (i) that for some, the self is something that can become fractured and disassembled, needing various activities to compose it afresh, one of which is reading, but all of which would involve introspection of some variety; and (ii) such activities require a turn away from normal social life, 
which, on Augustine's testimony, would have been characterized by the communal activities of debate or reading texts aloud, vestiges, perhaps, of the oral traditions of the past.

On the face of things, this turning toward the self is a phenomenon in opposition to the movements of argumentation, particularly social argumentation, which moves centrifugally towards an audience. Argumentation takes place "out there", modifying the environments in which audiences operate. But Perelman and Olbrechts-Tyteca (1969) also identified among the central notions of audience (along with the single hearer and the universal audience) the deliberating subject. While some commentators find the idea of the self as an audience improbable if not incomprehensible (see Johnson, 2013), Perelman and Olbrechts-Tyteca insist that this audience plays an important normative role when an individual "deliberates or gives himself reasons for his actions" (1969, p. 30). Perelman himself having raised the question "What is this audience around which argumentation is centered?" (1982, p. 13) repeats the definition of the New Rhetoric, that it is the gathering (or ensemble) of those who the speaker wishes to influence. Such a "gathering" would seem by its suggested plural nature to preclude the subject who deliberates, but Perelman immediately claims otherwise: "What is this gathering? It is highly changeable. It can be the speaker himself, reflecting privately about how to respond to a delicate situation" (p. 14).

Equally interesting to the idea of the self-deliberator as a type of audience is the way certain scholars have turned self-deliberation into a rhetorical strategy. Arguing with oneself, especially when that self is distanced in some way from the individual involved, through anonymity or across time, employs self-deliberation beyond the ends that Perelman assigned to it. Yet the latter phenomenon would seem in some way to depend on or be associated with the former. In this paper, my goal is to explore the nature of the selfdeliberator as an audience and self-deliberation as a rhetorical strategy employed in argumentation. 


\section{Self-deliberator as Audience: Perelman's Account}

A barrier to thinking of the self as an audience is the distinct roles played by arguer and audience. Arguers address audiences, and audiences are addressed. The roles can be reversed during argumentative exchanges, and often are, but the roles cannot be held simultaneously. Situations in which argumentation arises maintain a distance between the roles. So, becoming one's own audience during deliberation seems at best atypical. Ambrose searched for meaning in his heart and not through a shared experience, but in all other respects his activity was no different than before. Is the selfdeliberator so different?

Of course, we have no difficulty with the idea of self-deliberation itself; it is a natural form of introspection. We weigh reasons, think through alternatives, dismiss claims, and draw conclusions, all as part of the process of reasoning. We work out the details of a case, organize it appropriately, and then present it to others, seeking their approval as we have found it ourselves. ${ }^{1}$ What Perelman and Olbrechts-Tyteca do that prompts resistance is introduce the notion of audience into this structure. In this way, they recast the process as one that mirrors the social experience. I am an audience to myself as I am an audience to others. It is that as which bears consideration.

While allowing that self-deliberation is characterized by special features, Perelman and Olbrechts-Tyteca still focus on it as a particular kind of argumentation distinct from the traditional privileging of individualistic speech. Such an attitude has encouraged looking in the wrong direction-first to the self, then to others. They argue against this view: "Agreement with oneself is merely a particular case of agreement with others. Accordingly, from our point of view, it is by analyzing argumentation addressed to others that we can best understand self-deliberation and not vice versa" (1969, p. 41).

This direction of movement may seem counterintuitive to some, perhaps influenced by Descartes' claim that all he can know is his own thinking nature and that knowledge needs to be built

1 I leave outside the perimeters of this study the question of whether it is better to deliberate alone, or what benefits might be involved. This has been explored elsewhere (See Hample, 2018, p. 142; Gilbert, 2014). 
up (and outward) from there, or believing that humans evolved out of competition rather than cooperation. But recent work on the evolution of arguing has suggested that humans first learned to argue cooperatively together, persuading each other in social setting and as a result of that experience then learned to reason internally (Mercier \& Sperber, 2017, p. 109ff.; Hample, 2018, p. $144 \mathrm{ff}$. See also Santibáñez Yáñez, 2012). Such studies support many of the intuitions in the New Rhetoric project. Hample captures the point succinctly when, speaking of the Mercier and Sperber account, he observes: "If reasoning developed as a sort of self-defense [...] then it has an essentially social origin, not a private interior genesis. We can certainly think when we are alone, but the natural site for reasoning was in interaction with other people" (2018, p. 146).

Much of Perelman and Olbrechts-Tyteca's subsequent discussion involves ways in which a decision is justified or rationalized with reasons that were not apparent at the moment of decision. Thus, the self-deliberator is often deemed to be involved in such a process of rationalization. For Perelman and Olbrechts-Tyteca, argumentation is always a function of the audience being addressed. Insofar as self-deliberation involves argumentation, it must also involve an audience. "Consequently", they conclude, "it is legitimate that the person who has acquired a certain conviction should be at pains to strengthen it for himself and, more especially, against possible attack from without" (1969, p. 44). In such a manner, with new reasons, a conviction is intensified. Argumentation is not just aimed at persuasion; among its many goals is the reinforcement of premises to which one already adheres. Moreover, there is an expectation of consistency between the arguments a person puts forward to others and the arguments that person accepts.

So, much of what Perelman and Olbrechts-Tyteca have to say about the self-deliberator as audience suggests processes preliminary to making an argument public, but it is no less argumentative in nature. Individuals understand the positions they hold by finding the reasons that support them. Or they reinforce their positions with further reasons that strengthen their adherence. Understanding and reinforcement are thus important outcomes of the argumentation addressed to this audience, quite apart from the traditional sense 
of deliberation that involves the weighing of reasons in coming to a conclusion. This reinforcement can be extended to accommodate the kinds of reconstitution implied by the traditional sense of recreation; rebuilding the self and its beliefs anew by strengthening the structure of adherences on which it is erected.

Also assumed here is a certain conception of the 'self'. Later in the New Rhetoric project, Perelman and Olbrechts-Tyteca discuss the relationship between a person and the acts they perform. This arises in the section of the work that deals with argumentation based on the structure of reality (rather than that which establishes that structure), so there is a necessary assumption of stability assigned to the person; it is part of the reality, part of the given in an argumentative situation (1969, p. 300). This stability is what allows us to anticipate a person's actions. We expect their character, formed over time, to influence what they do, or don't do. Thus, we are not surprised when someone acts as expected, and we are surprised when they act in ways that we judge to be "out of character". No action is ever guaranteed, but it is more or less likely: "As another person's intention cannot be known directly, it can be presumed only from what is known of the permanent aspects of the person. Sometimes intention is revealed by repeated, concordant acts, but there are cases in which it can be determined only from the idea one has of the agent" (p. 301).

At the same time, argumentation is an important element in the development of personhood, and they recognize this. As much as the person has a stable structure at any particular time, it is still undergoing change: "the construction of the person is never finished, not even at his death" (p. 296). So, there is a tension here between the person or self ${ }^{2}$ that underlies the relatively fixed character (that in turn underlies the acts) and the future self that is in process, and that may act otherwise, and believe otherwise, and even argue otherwise.

This is not the place to explore the role that argumentation plays in developing and maintaining personhood; ${ }^{3}$ the point to

2 In spite of the recognized differences involved in these concepts, I use the terms synonymously for the purposes of this discussion.

3 I explore this elsewhere. See Tindale (2011). I will discuss something of the nature of the self below. 
carry forward is that the self addressed in self-deliberation, the audience in question, may not be the fixed self seeking justifying reasons but the future self who is yet to act. C. S. Peirce makes a similar point: "Let anybody call to mind some recent earnest self-deliberation, and I think he will acknowledge that it took a dialogic form, every reasoning appealing to the self of the near following moment of time for assent and confirmation" (Peirce, 1998, pp. 428-429). ${ }^{4}$ The self I must persuade, with whom I deliberate, may not be the self of the present, but the self of the next moment. I am not static; I am a dynamic force in motion, using similarly dynamic processes at my disposal. The audience I must persuade and move to action lies (just) in the future. This was a point already argued by Socrates in Plato's dialogues.

\section{Socrates the Self-deliberator}

There is something of the silent reader in the self-deliberator, taking a public practice and retreating with it into the private sphere. But if the silent reader is inaugurated in Ambrose, the introspective reasoner has an earlier precedent in the figure of Socrates.

Socratic inquiry is, to a degree, an invitation to self-deliberation. As Mercier and Sperber put it, "help your interlocutors see in their own beliefs reasons to change their views" (2017, p. 197). This-what we might call-"assisted-self-deliberation", captures the nature of Socratic argument as it is invested in the so-called experts that he meets. ${ }^{5}$ In soliciting a claim from an interlocutor (usually related to a definition that would express that person's expertise), Socrates then invites the individual to explore that claim with him, to test it to see if the person has the knowledge to support it. This involves going back into the belief system of the interlocutor. This is a direction of travel that argument encourages. Where does the argument take us? asks Socrates. It should take us back into ourselves to understand our own position. And, as we have seen, this is part of the project of self-deliberation, using argument to understand oneself.

4 I am grateful to Philip Rose for drawing this to my attention.

5 This is generally termed elenctic argument, or refutation. I would distinguish it from other types of Socratic argument like the hortatory or maieutic, but such concerns are beyond the current discussion. 
This is distinct, however, from Socrates' own self-deliberative practice, in which he uses himself as an audience that he needs to persuade. We see this in dialogues like the Phaedo, Theaetetus, and Greater Hippias. ${ }^{6}$

In the dialogues that he devotes to the Sophists (and they are frequently present in the Platonic corpus), Plato presents them as exponents of public argument. In this, they express the negative, counterside to the kind of invitational, communal argumentation fostered in the Dialogues. But there is a very different treatment of argument conveyed through some of the statements of Socrates. In the Phaedo, for example, after criticizing the Sophists for giving argument a bad reputation and thereby leading people to hate it, Socrates advocates the pursuit of truth and knowledge through the use of good arguments (90d). He then surprises us, perhaps, by claiming that what is important is not persuading those who hear him, but rather himself: "I shall not be eager to make what I say seem true to my hearers, except as a secondary matter, but shall be very eager to make myself believe it" (91b). And how might he make himself believe what he says? This advocacy of introspection seems quite at odds with the general Socratic practice of "reasoning together" to ascertain what is true. Until we consider that there is still a dialogue involved, but this time an internal one.

A passage in the Theaetetus makes this clear. There, Socrates defines thought as a speech (logos) that the soul has with itself: "the soul is conversing with itself, asking itself questions and answering, affirming and denying" (190a). In ways that invite further study, this passage takes the typical Socratic Method of questions and answers and internalizes it, making the questioner and answerer, the speaker and audience, one and the same person.

This sense of the self as an audience for its own deliberations is nowhere clearer than in an extended discussion between Socrates and the Sophist Hippias in the Greater Hippias. Hippias is an advocate of the large, expansive speech, and contrasts this with the Socratic propensity for the "flakings and clippings of speeches". This

6 Elsewhere (Tindale, 2010) I have called this "private argument", to contrast it with the public, communal practices of argumentation promoted in the dialogues. 
approach takes the mass of a thing and divides it up with words, freezing things in isolation for examination, and tearing them from the natural flux. Hippias is concerned that this separates things from their natural context. What Hippias values is to be able to present a speech well, and to successfully persuade others of one's case (304b).

There is more to the exchange between Hippias and Socrates over the relative merits of types of speech. But of greater interest is a strategy employed in the Greater Hippias. Socrates does not directly attack the points raised by Hippias, instead he invokes a shadowy dissenter (someone who he accuses of questioning him quite insultingly, 286c-d), and then he takes on the persona of that other man, so that Hippias is to answer Socrates as if this other is the actual questioner (287c). Socrates stresses how important it is that he, Socrates, be able to convince this other man, who he eventually identifies as Sophronicus' son, that is, Socrates himself: "who wouldn't easily let me say those things without testing them" (298c). Let us be clear about what is being presented here: Socrates requires from Hippias an argument that he can take away and use to convince a third party, who turns out to be Socrates himself.

What strategy is behind the employment of this device? Perhaps it is to allow Socrates to insult someone who is so antithetical to everything that Plato represents, given Hippias' boasting of his proficiency in so many areas. Thus, Hippias is thought to be the Sophist who Plato sees most fit for ridicule. But Socrates states often that he agrees with the insults of this other man, so he is hardly a buffer between the insults and the person insulted. Rather, we might see in this device Plato stressing here (as he does elsewhere) a preference for private, internal argumentation over that which is public. Where Hippias promotes argumentation in the public domain, Plato, on this occasion, promotes the internal dialogue of self-deliberation. Socrates' venture into the public, on these terms, is to harvest arguments with which he can withdraw into the private sphere and deliberate upon.

7 The same point is made in the Lesser Hippias (369b-c).

8 See Woodruff (1982, p. 43, n47; p. 108) for a discussion of the controversy surrounding Plato's use of this device. Some see it as non-Platonic, but Woodruff makes a strong case for its authenticity. 
Two things might be noted here: (i) when Socrates' interlocutors are invited to reflect on their own statements, making of themselves an audience for their own investigations, the self involved is one of a present time, already constituted and in possession of beliefs that are to be justified or not; while for Socrates, when he deliberates with himself, his audience is a self of a future time, one who does not yet hold such a belief but is open to considering it. (ii) The device in the Greater Hippias, while making the point clearer than in the earlier passages from other dialogues, is also demonstrative in a way they are not. Socrates conjures up an explicit other (Sophronicus' son) with whom to deliberate. As such he will inaugurate a rhetorical strategy that can be shared by others, as we will see in section 5 . The recourse to such a device here might also suggest that we are witnessing something that is conceptually new and difficult to convey. Thus, a short discursive on how the self has been read in Plato is in order.

\section{The Self that Deliberates}

It might be objected that the sense of the self that interests Perelman and Olbrechts-Tyteca when they assert the self-deliberator as a type of audience is a far more developed metaphysical entity than any sense of self that would have been recognized by Plato. Whether the Ancients had a "modern" notion of the self has been the subject of serious discussion in the relevant literature. In the space I have here, I will restrict the discussion to the "pro" case.

As Christopher Gill (2006, 1991) observes, there are clear dangers in reading a modern conception of the self back onto Greek thought. He finds no uncontroversial grounds for identifying a modern (post-Cartesian) notion of "person" in Greek thought (1991, p. 193). Others expect to see a development of ideas from the Greeks through to modern times, and so, perhaps unsurprisingly, find such a development present. Charles Kahn (1988), for example, sees the idea of an individualized "I" of "personal identity" first emerging in Epictetus and his use of the term prohairesis (translated as "choice" or "decision"-Kahn, 1988, p. 53). 
What the passages I have explored would seem to confirm is a conception of the person as what Gill has called "in dialogue", where the person becomes the focal point of three related types of dialogue: dialogue with others as engaged participants in society; dialogues with others in debate over the principles of human experience; and an internal dialogue between the parts of the psyche (Gill, 1996, passim). All three are viable senses of dialogue in Plato's work, with the first two receiving the bulk of attention. It is the last of these that I have stressed, but the relationship between them is something to be considered.

\section{Dialogues with the Self: Descartes and Booth}

There might not be two more unlikely companions than René Descartes, the anti-rhetorical rationalist, and Wayne C. Booth, the rhetorical theorist and literary critic. But both found merit in the strategy of dialoguing with the self, Descartes through the creation of an anonymous correspondent, and Booth through dialogue with his 14-year-old former self. In both cases, we see the introduction of an audience with whom the writer enters a dialogue. My interest is in what might be achieved by the use of such a strategy.

The author here is distanced from himself, creating another stance through which to look at (and maybe judge) himself. This thinking bears resemblance to the strategy of creating a "false" standard of objectivity that is supposedly neutral, like the "Martian standard" (Tindale, 2004). Such standards are false in that the objectivity they claim is a fiction. There is no Martian standard, for example; we cannot Google it to learn what is involved. It is simply a projection of the person who creates the standard, and thereby controls it. The strategy in question is more concrete and involves a real person-the author.

Descartes employs the device in the Preface to his last book, The Passions of the Soul (1649), a book that he was apparently reluctant to publish. The Preface consists of two letters to Descartes from an anonymous correspondent, advocating for the publication of the book, along with two short replies from Descartes. There is 
the possibility that the author of the letters may have been one of Descartes' regular correspondents, but the weight of scholarship favours the philosopher himself having authored both the letters and the replies (See Caton, 1982). ${ }^{9}$

The first letter begins by indicating directly Descartes' reluctance to deliver himself of the treatise on the Passions he has promised because he had failed to provide it to the anonymous author. Motives for such reluctance are recounted, including a righteous indignation on Descartes' part towards the ingratitude of the public for what he had previously accomplished, and the ignorance of commentators who have commented negatively. The anonymous author entreats and coaxes Descartes with praise of his accomplishments in terms that the principles of humility must dissuade any author of using explicitly for themselves: "there has never been anyone but you alone [...] who has discovered the true principles and recognized first causes of everything brought forth in nature" $(1989$, p. 5). Thus, there is irony in the request to abandon his "excessive modesty" and fulfill his obligations to science and the public (p. 7). Discounting the accomplishments of Aristotle (prone to error) and the Scholastics (uncertain reasonings), Descartes' Method is championed as "so infallible" that he "never fail[s] to find out by means of it everything the human mind can about the things" he investigates (p. 10).

Eventually, the real likely cause of Descartes' hesitation is brought to light with the identification of the high costs of such research, which the letter writer appreciates Descartes cannot undertake at his own expense. The writer ends by noting that although France is powerful enough to fund this research, "nevertheless, because the other nations have no less an interest in it than she does, I'm sure that many would be generous enough not to yield to her in that capacity" (1989, p. 15).

Interestingly, Descartes responds to this first letter that since it lists so much to his credit, people will suspect collusion between the

9 Caton observes that anonymous authorship was common in the seventeenth century, although motives for such anonymity varied. Caton reviews the evidence and concludes that the Preface itself identifies its author directly as Descartes by virtue of several characterizations, chief of which is the author's claim to know "by personal knowledge" Descartes' intimate motives (1982, pp. 302-305). 
author and himself! He advises against publication, in part because he does not think the plan behind it will be successful, and also because it misreads his motives: he had refused the writer what he had written about the Passions only to avoid any obligation to show it to others who would not understand it.

The second, very short letter reiterates the plan to prompt those who have access to funds to procure them for Descartes' work. And Descartes' also short second reply explains that the delay in sending the treatise has been due to minor revisions, now complete, and hopes that those who read it "will take the trouble to examine it carefully" (1989, p. 17), for only such would a reader be satisfied.

We might observe of Descartes' "anonymous" Preface that it is unlike the dialogue form used by other authors to explore ideas because it directly concerns Descartes himself and his work. And it is not self-deliberation between a self and a future self because here the conclusions have already been reached. What we are receiving is justification, plausibly the justification reached by Descartes through self-deliberation. The Preface is a device to convey the results of his internal dialogue. But why this device in particular?

Among the rhetorical strategies that seem favored by Wayne Booth is that of entering into conversations with various non-present others. It has the merit of making present ideas by personalizing the discussions and giving them a sense of process and immediacy. In his lengthy analysis of the philosopher Bertrand Russell's rhetoric (Booth, 1974), for example, not only does Booth create a textual portrait of a variety of Russell's representing different aspects of his work, he also at one point (about mid-way through the chapter) constructs a dialogue between himself and Russell (1974, pp. 68-73). My interest is not in the analysis of Russell's thought that Booth provides, but in his strategy of analysis.

The "dialogue" consists of various series of quotes from Russell's work and an immediate reply from Booth (identified as "Q", presumably for questioner), and an occasional comment on the exchange in square brackets. For example, it begins:

R: "Man is a part of Nature, not something contrasted with Nature". 
Q: I agree, but this seems to me to be precisely what you deny when you choose to rule out all of man's values as irrelevant to Nature.

Since the quotes are drawn from Russell's work, then the dialogue is not completely invented; Russell actually wrote the many quotes (there are 39 included, some quite long) that are all taken from the first chapter of his book What I Believe, published in 1925, over forty years earlier. ${ }^{10}$ But, of course, Russell didn't write them so as to respond to Booth's questions in the argumentative situation that has been created here, nor were they intended to address the overall concern governing Booth's lecture. In this sense, the dialogue is artificial; Booth controls both sides of the "exchange" in the sense that he chooses what quotes to extract from Russell and how to arrange them in relation to his questions. Booth is not strictly talking to himself, but he is talking to a Russell that he has constructed from the text, an other that is being employed to support the points that Booth is making. As a strategy it personalizes the analysis by inviting Russell in, giving him a place in the performance, allowing him to speak in his own voice. But it is all filtered through Booth's arrangement, particularly because Booth has identified three Russell's in the philosopher's writings-Russell I is the logician; Russell II the man of rational protest; and Russell III "the poet and mystic" (Booth, 1998, p. 47) -and while the dialogue engages a text belonging to Russell III, some of the responses concern the views of the other Russell's. The pseudo-dialogue is an effective way to illustrate Booth's claim that there is a "conflict between the three Russell's" (1998, p. 52).

My point in drawing attention to the dialogue with "Russell" is to show that this is a rhetorical strategy that Booth favours as a way to make ideas present. More appropriate to the current discussion is the dialogue Booth has with himself, albeit an earlier version. This is a stronger companion case to that of the Descartes example.

Ostensibly, the purpose behind the dialogue with the younger self is to measure the changes that have taken place in his Mormon beliefs. The 14-year-old was a 100-percent devotee, fundamentalist in

10 Modern Dogma and the Rhetoric of Assent is based on a series of lectures Booth gave at the University of Notre Dame in April of 1971. 
his views; the older Booth is still Mormon but without the strongly held beliefs. "The pious young believer and I have engaged in a variety of dialogues for going on seven decades". And the boy has often been shocked by the changes in belief of the man he became. Now, the older Booth looks for reconciliation of a type:

Isn't it time, I now ask my young self, to probe beneath the superficial "verbal" differences to the true grounds of our strongest convictions? Isn't our real assignment, as we approach the new millennium, to discover what we share and then decide, probing our differences, just what can be cast aside? (1998, p. 2).

But the boy's imagined responses are accusatory: the older man has betrayed his forbearers, can no longer be considered a Mormon, and holds metaphorically what he once took as literal. The older Booth is unrepentant. He believes there is more connecting them than dividing them: "But I go on arguing-as I shall argue here-that beneath our differences, he and I still share common ground that is far more important than our differences" (1998, p. 2). And that this serves as an introduction into Booth's theory of rhetorology: "not rhetorical persuasion but rather a systematic, ecumenical probing of the essentials shared by rival rhetorics in any dispute" (p. 3). This leads to a long excursion through his journals, relaying events from his time as a Mormon missionary, as he encountered other rhetorics and learned to listen and modify his views through that listening (that is, through rhetorology). ${ }^{11}$

The dialogue with the 14-year-old self had simply been an entrée into a world of dialogues with others, all of whom had had something to teach him as he listened. Thus, the pseudo-dialogue in this case serves as an example of the value of dialogical listening that his form of rhetoric requires.

These are examples of self-deliberation. But the strategy is interesting, because the other self is disguised, cloaked in anonymity (Descartes), or in the person of a past self. So, this is not selfdeliberation as we have earlier seen it. The conclusions are already reached. This is a strategy of justification.

11 "What my practice of rhetorology as a missionary taught me was that if I pretended to listen sympathetically to beliefs I detested, I would sometimes discover that they were better beliefs than those I had held when entering the discussion" (Booth, 1998, p. 16). 


\section{Consequences for Argumentation Theory and Further Research}

The emergence of the study of argumentation schemes has a fascinating point of relevance with the current discussion because of the importance of certain schemes like the scheme for Practical Reasoning (Walton, Reed, \& Macagno, 2008). As presented by Walton et al. in their compendium of schemes, it has a markedly internalistic atmosphere to it.

Argumentation schemes are common patterns of reasoning that issue in conclusions judged defeasible in nature. ${ }^{12}$ The scheme for Practical Reasoning has the following structure:

Major Premise: I have a goal G.

Minor Premise: Carrying out this action A is a means to realize G.

Conclusion: Therefore, I ought (practically speaking) to carry out this action A (Walton et al., 2008, p. 323).

It will be immediately apparent that self-deliberation, as we have discussed it, is a far more complex process than what is suggested in this scheme. But each argumentation scheme is accompanied by a set of Critical Questions that are intended to assist any evaluator in judging the quality of an argument of that scheme. It is in the Critical Questions for the scheme for Practical Reasoning that this complexity comes to light. Walton and his co-authors provide five such questions:

CQ1: What other goals that I have that might conflict with G should be considered?

CQ2: What alternative actions to my bringing about $\mathrm{A}$ that would also bring about $\mathrm{G}$ should be considered?

CQ3: Among bringing about $\mathrm{A}$ and these alternative actions, which is arguably the most efficient?

CQ4: What grounds are there for arguing that it is practically possible for me to bring about $A$ ?

CQ5: What consequences of my bringing about $A$ should also be taken into account? (Walton, et al., 2008, p. 323).

12 That is, they are drawn on the available evidence, but future evidence may lead to their modification or even refutation. 
Here in rich variety are the musings of the self with itself, weighing alternatives, identifying goals and coming to decisions. The very concept of a goal as conceived here (and by other argumentation theorists, like Gilbert and Hample) assumes a conception of selfunderstanding and, beneath this, a conception of self along the lines I have discussed in this paper. This future-oriented self listens to itself as it provides answers to the critical questions. Here we would seem to have a modern version of what I described above as "assistedself-deliberation". ${ }^{13}$

Finding self-deliberation embedded in contemporary argumentation schemes discloses a thread of focus running through modern argumentation studies. While central interests of social argumentation mean that the bulk of attention is directed to deliberating and arguing with others, we should not overlook the importance of arguing with the self and the relation this has to arguing with others.

Moreover, two important goals for such self-deliberative argumentation have come to light, depending on whether the arguer is concerned to justify a position already taken or provide reasons for the actions of a future self. More research on this distinction will likely produce frutiful results.

And there are further avenues of research suggested by what has been discussed. What is the role of self-deliberation, for example, in the relationship between conviction and persuasion? Agents are often convinced of things while not being moved to actions that support such conviction. We may be convinced of certain health hazards or of the harms of climate change without being moved to alter our behaviour in any way. What is required is uptake on our part, as the general concern becomes personalized. In other words, individuals need to become persuaded of things about which they already have the arguments to support conviction, and thereby moved to act on those arguments. This move from conviction to persuasion would seem to require self-deliberation.

13 The scheme for Practical Reasoning is not the only relevant one in the compendium provided by Walton et al. (2008). I use it simply to ilustrate my point. But other schemes that involve an internal dialogue include the Argument from Sunk Costs (2008, pp. 326327); Reasoning from Negative Consequences (p. 332); Argument from Plea for Excuse (p. 345); and Argument from Memory (p. 346). 
Finally, there are more practical applications for this work. For example, does the idea of an intelligent autonomous agent build on the traditional sense of self-deliberation? Douglas Walton (2016) defines an intelligent autonomous agent (IAA) as follows: "an entity that has the capability of forming goals and the capability of carrying out actions that it thinks might realize one or more of its goals. An agent in this sense can be a machine or a human (or an animal)" (2016, p. 2). While for Walton, this is a natural extension of how agency operates in argumentation schemes (and offers the promise of building intelligent systems that model human reason), for us this sounds remarkably like the self-deliberator of argumentation theory.

As we study the nature of deliberative argumentation in social and political situations, with all the importance granted to such study and the valuable results it promises, we should not lose sight of the single reasoner, deliberating with herself, justifying and anticipating, reconciling the past and deciding the future. Because such a deliberator underlies many of the issues that impact collective actions, and offers lessons useful for a fuller account of how argumentation operates in our societies $\mathbf{I}$

\section{References}

Augustine (1961). The Confession of Saint Augustine (E. B. Pusey, Trans). Collier Books.

Augustine (1991). Confessions. Henry Chadwick (Trans). Oxford University Press.

Booth, W. (1974). Modern Dogma and the Rhetoric of Assent. University of Notre Dame Press.

Booth, W. (1998). Confessions of an Aging, Hypocritical Ex-Missionary. Sunstone, 21(109), 25-36. https://www.sunstonemagazine.com/pdf/109. 25-36.pdf

Caton, H. (1982). Descartes' Anonymous Writings: A Recapitulation. The Southern Journal of Philosophy, 20(3), 299-311. https://doi. org/10.1111/j.2041-6962.1982.tb00298.x 
Davies, R. (2015). A Celtic Temperament: Robertson Davies as Diarist. McClelland \& Stewart.

Descartes, R. (1989 [1649]). The Passions of the Soul (S. H. Voss, Trans.). In Hackett Publishing.

Gilbert, M. (2014). Arguing with People. Broadview Press.

Gill, C. (1991). Is There a Concept of Person in Greek Philosophy? In Stephen Everson (Ed.), Companions to Ancient Thought: 2: Psychology (pp. 166-193). Cambridge University Press.

Gill, C. (1996). Personality in Greek Epic, Tragedy, and Philosophy: The Self in Dialogue. Oxford University Press.

Gill, C. (2006). The Structured Self in Hellenistic and Roman Thought. Oxford University Press.

Hample, D. (2018). Interpersonal Arguing. Peter Lang.

Johnson, R. (2013). The Role of Audience in Argumentation from the Perspective of Informal Logic. Philosophy and Rhetoric, 46(4), 533-549. https://doi.org/10.5325/philrhet.46.4.0533

Kahn, C. (1988). Discovering the Will: From Homer to Augustine. In J. Dillon and A.A. Long (Eds.), The Question of 'Eclecticism': Studies in Later Greek Philosophy (pp. 234-259). Berkeley: University of California Press.

Mercier, H. \& Sperber, D. (2017). The Enigma of Reason. Harvard University Press.

Peirce, C. (1998). Pragmatism. In The Peirce Edition Project (Eds.), The Essential Peirce, volume 2 (1893-1913) (pp. 398-433). Indiana University Press.

Perelman, C. \& Olbrechts-Tyteca, L. (1969). The New Rhetoric: A Treatise on Argumentation (J. Wilkinson, \& P. Weaver, Trans.). University of Notre Dame Press.

Perelman, C. (1982). The Realm of Rhetoric. University of Notre Dame Press.Plato. (1997). Plato: Collected Works (J. M. Cooper, Ed.). Hackett.

Santibáñez Yáñez, C. (2012). Mercier and Sperber's Argumentative Theory of Reasoning: From Psychology of Reasoning to Argumentation 
Studies. Informal Logic, 32(1), 132-159. https://doi.org/10.22329/ il.v32i1.3536

Tindale, C. W. (2004). Rhetorical Argumentation: Principles of Theory and Practice. Sage.

Tindale, C. W. (2010). Reason's Dark Champions: Constructive Strategies of Sophistic Argument. University of South Carolina Press.

Tindale, C. W. (2011). Out of the Space of Reasons: Argumentation, Agents and Persons. Pragmatics and Cognition, 19(3), 383-398. https:// doi.org/10.1075/pc.19.3.01tin

Walton, D. (2016). Intelligent Practical Reasoning for Autonomous Agents: An Introduction. Review of European Studies, 8(1), 1-20. http://dx.doi. org/10.5539/res.v8n1p1

Walton, D., Reed, C. \& Macagno, F. (2008). Argumentation Schemes. Cambridge University Press.

Woodruff, P. (1982). Plato: Hippias Major. Hackett. 